\title{
SIMULASI PENCAMPURAN REAKTAN UNTUK PRODUKSI BIODIESEL PADA REAKTOR BERPENGADUK STATIK
}

\section{SIMULATION OF REACTANT MIXING IN BIODIESEL PRODUCTION USING STATIC MIXING REACTOR}

\author{
Ni Putu Dian Nitamiwati ${ }^{1)}$, Armansyah Halomoan Tambunan ${ }^{2 *}$, dan Lilik Pujiantoro Eko Nugroho ${ }^{2)}$ \\ ${ }^{1)}$ Program Studi Magister Teknik Mesin Pertanian dan Pangan, Institut Pertanian Bogor \\ ${ }^{2}$ Program Studi Teknik Mesin dan Biosistem, Institut Pertanian Bogor \\ PO Box 220, Kampus IPB Darmaga, Bogor, Jawa Barat 16680 \\ E-mail: ahtambun@apps.ipb.ac.id
}

Makalah: Diterima 6 Mei 2018; Diperbaiki 15 Oktober 2018; Disetujui 25 Oktober 2018

\begin{abstract}
Application of static mixer is expected to enhance yield of biodiesel production and reduce catalyst requirement. Static mixer could increase the mixing effectiveness of oil and methanol, so that FAME yielded at the reactor would increase and could reach the desired level of conversion with lower catalyst requirement.A more in-depth study of the mixing and its relation to the effectiveness of transesterification reactions is indispensable to obtain important parameters which is necessary in process improvement and reactor design. The objective of this study was to examine the flow profile and its relation on mixing of oil and methanol in a continuous type reactor using computational fluid dynamics (CFD). Simulation was conducted using five scenarios of mass flow rate in the range of 5-20 L/min for oil and 0.6-2.4 L/min for methanol. It was observed that the static mixer elements can increase the uniformity of vorticity, which indicates that the flow is not only moved on the mainstream (axial direction) but also moves toward the y-axis and the z-axis randomly as well as rotational motion. The uniformity of vorticity along the static mixing reactor provided a better chance of mixing and increase the possibility of reactions between molecules of reactant.
\end{abstract}

Keywords : biodiesel, transesterification, static mixer, computational fluid dynamics (CFD), vorticity

\section{ABSTRAK}

Penggunaan pengaduk statik untuk produksi biodiesel mampu memberikan hasil yang baik, serta dapat mengurangi penggunaan katalis. Pengaduk statik dapat meningkatkan ketercampuran minyak dan metanol sehingga FAME yang dihasilkan pada modul kelima meningkat dan diharapkan dapat mencapai tingkat konversi yang diinginkan dengan penggunaan katalis yang lebih sedikit. Kajian lebih mendalam mengenai tingkat ketercampuran serta kaitannya dengan efektivitas reaksi transesterifikasi yang terjadi perlu dilakukan untuk mendapatkan parameter penting dalam perbaikan proses maupun rancangan reaktor. Tujuan penelitian ini adalah melakukan kajian terhadap profil aliran di dalam reaktor berpengaduk statik tipe kontinu dan kaitannya dengan ketercampuran minyak dan metanol di dalam reaktor menggunakan metode computational fluid dynamics (CFD). Simulasi dilakukan dengan lima skenario laju aliran massa pada kisaran 5-20 L/menit untuk minyak dan 0,6-2,4 L/menit untuk metanol. Hasil simulasi menunjukkan bahwa keberadaan elemen pengaduk di dalam pipa reaktor berpengaduk statis dapat meningkatkan keseragaman vortisitas aliran fluida, sehingga aliran fluida tidak hanya terjadi ke arah arus utama (arah aksial) tetapi juga terjadi gerakan acak ke arah sumbu y dan z, serta gerakan rotasi. Keseragaman vortisitas di sepanjang reaktor pengaduk statik memberi peluang ketercampuran molekul-molekul reaktan yang lebih baik, dan meningkatkan peluang terjadinya reaksi antar molekul reaktan.

Kata kunci: biodiesel, transesterfikasi, pengaduk statik, computational fluid dynamics (CFD), vortisitas

\section{PENDAHULUAN}

Produksi biodiesel melalui reaksi transesterifikasi melibatkan dua reaktan, yaitu trigliserida dan alkohol, untuk menghasilkan senyawa alkil ester dan gliserol (Knothe et al., 2005). Senyawa alkohol yang sering digunakan pada reaksi transesterifikasi adalah metanol. Trigliserida merupakan fraksi terbesar dari minyak atau lemak, sedangkan metanol merupakan senyawa alkohol dengan rantai atom karbon paling pendek yang bersifat reaktif. Metanol memiliki sifat kepolaran yang tinggi sehingga memiliki kemampuan yang baik untuk melarutkan, khususnya untuk melarutkan katalis basa (Ma dan Hanna, 1999). Akan tetapi, metanol dan minyak mempunyai sifat immiscible yaitu sulit bercampur dan akan membentuk dua lapisan. Terbentuknya lapisan tidak bercampur ini akan menghambat terjadinya reaksi antar molekul minyak dan metanol.

Beberapa penelitian telah dilakukan untuk meningkatkan ketercampuran minyak dan metanol, antara lain dengan melakukan pengadukan yang lebih kuat. Pengadukan yang kuat akan 
mempermudah difusi metanol dalam minyak karena hambatan transfer massa dalam minyak menjadi berkurang (Budiman et al., 2017). Pengadukan juga dapat meningkatkan energi kinetik reaktan, sehingga peluang terjadinya tumbukan antar reaktan semakin besar (Ma dan Hanna, 1999; Darnoko dan Cheryan, 2000; Garpen, 2005). Untuk itu, pemilihan jenis atau metoda pengadukan menjadi penting, seperti penerapan jenis pengaduk statik.

Pengaduk statik adalah salah satu jenis pengaduk yang sudah banyak digunakan pada proses pencampuran bahan pangan, akan tetapi belum diterapkan untuk produksi biodiesel. Pengaduk statik tipe helikal tersusun dari beberapa buah elemen dari plat logam yang dipuntir dengan sudut $180^{\circ}$. Elemen pengaduk tersebut disusun secara aksial dengan masing-masing ujung elemen dipasang tegak lurus satu sama lain kemudian dimasukkan ke dalam sebuah pipa (Kumar et al., 2008). Bahan yang dilewatkan di dalam pengaduk statik akan mengalami proses pembagian, peregangan, pembalikan, dan pencampuran. Proses inilah yang mengakibatkan bahan-bahan bercampur lebih baik. Jika dibandingkan dengan pengaduk mekanis, pengaduk statik memerlukan biaya pengoperasian dan perawatan yang rendah. Hal ini dikarenakan pada pengoperasian pengaduk statik, fluida dialirkan hanya memerlukan pompa dan ketiadaan komponen bergerak.

Penggunaan pengaduk statik untuk produksi biodiesel mampu memberikan hasil yang baik. Panggabean (2011) menunjukkan produksi biodiesel dengan reaktor pengaduk statik tipe semi kontinu dapat menghasilkan nilai konversi sebesar 95,82\% (b/b) dengan katalis KOH 0,5\% (b/b) selama 30 menit. Berikutnya, Soolany et al. (2015) melakukan penambahan jumlah elemen pengaduk statik dan memperoleh yield sebesar 97,04\% (b/b) dengan katalis $\mathrm{KOH} 0,5 \%$ (b/b) dan waktu reaksi 37 menit. Perbandingan jumlah FAME antara pengaduk mekanik dan statik yang dilakukan oleh Sungwornpatansakul et al. (2013) menunjukkan dengan katalis $\mathrm{KOH} 0,6 \%(\mathrm{~b} / \mathrm{b})$, yield FAME sebesar $90 \%$ dapat dicapai dalam waktu reaksi kurang 5 menit, sedangkan pengaduk mekanik hanya mencapai $70 \%$ dalam waktu yang sama.Hasil penelitian tersebut menunjukkan bahwa pengaduk statik dapat meningkatkan ketercampuran minyak dan metanol yang ditunjukkan dengan meningkatnya yield produksi biodiesel, serta dapat mengurangi penggunaan katalis.

Berdasarkan hasil-hasil tersebut, telah dirancang sebuah reaktor produksi biodiesel tipe kontinu dengan menggunakan pengaduk statik. Reaktor tersebut memiliki lima buah modul pengaduk statik. Modul pengaduk statik merupakan pipa dengan panjang tertentu yang di dalamnya terdapat susunan beberapa buah elemen pengaduk statik. Penambahan jumlah modul pengaduk statik bertujuan untuk mendapatkan ketercampuran minyak dan metanol yang lebih baik sehingga FAME yang dihasilkan pada modul terakhir meningkat dan diharapkan mencapai tingkat konversi yang diinginkan. Kajian lebih mendalam mengenai tingkat ketercampuran serta kaitannya dengan efektivitas reaksi transesterifikasi yang terjadi perlu dilakukan untuk mendapatkan parameter penting dalam perbaikan proses maupun rancangan reaktor berpengaduk statik.

Analisis parameter ketercampuran antar molekul reaktan di dalam reaktor dapat dilakukan secara eksperimental atau analitik. Akan tetapi, metoda eksperimental cukup sulit dilakukan karena membutuhkan waktu dan biaya yang cukup besar, sedangkan metoda analitik menjadi rumit karena melibatkan teori pencampuran dan reaksi kimia secara simultan. Alat bantu yang banyak digunakan untuk melakukan kajian analitik dan simulasi adalah computational fluid dynamics (CFD). CFD juga banyak diterapkan pada proses perancangan ataupun perbaikan rancangan. Beberapa peneliti menggunakan metoda CFD untuk menyimulasikan pencampuran reaktan dengan melibatkan reaksi kimia pada reaktor tipe batch berpengaduk mekanik (Adeyemi et al., 2013; Wen dan Petera, 2015). Penelitian ini bertujuan untuk mempelajari profil aliran di dalam reaktor berpengaduk statik tipe kontinu dan kaitannya dengan ketercampuran minyak dan metanol di dalam reaktor berdasarkan simulasi CFD.

\section{BAHAN DAN METODE}

Bahan yang digunakan pada penelitian ini adalah minyak sawit, metanol, dan katalis kalium hidroksida $(\mathrm{KOH})$ pro analysis.

\section{Deskripsi Reaksi Transesterifikasi}

Reaksi transesterifikasi pada penelitian ini menggunakan reaktan minyak sawit dan metanol dengan rasio molar $1: 3$, seperti ditunjukkan pada Gambar 1. Komponen penyusun dari minyak sawit adalah $44,4 \%$ asam oleat, $43,4 \%$ asam palmitat dan $12,2 \%$ asam linoleat yang diasumsikan berdasarkan tiga komponen utama hasil pengukuran Sari et al. (2016). Suhu awal minyak dan metanol masingmasing adalah $65^{\circ} \mathrm{C}$ dan $28^{\circ} \mathrm{C}$. Reaksi menggunakan jenis katalis basa $\mathrm{KOH}$ sebesar $0,5 \%$ dari berat minyak. Pompa digunakan untuk mengalirkan reaktan dari masing-masing tabung yang terpisah melalui dua inlet yang berbeda dan bercampur di dalam modul pengaduk static.

\section{Metode Komputasi \\ Model Geometri}

Pembuatan model fisik dalam simulasi didasarkan pada prototipe reaktor berpengaduk statik tipe kontinu untuk produksi biodiesel yang digunakan pada penelitian Sari et al., 2016. 
<smiles>[R]C(=O)OCC(I)COC(=O)OCC</smiles>

Gambar 1. Persamaan kimia reaksi transesterifikasi (Sivasamy et al., 2009)
Elemen pengaduk statik yang digunakan berukuran $0,07 \mathrm{~m}$ x 0,036 $\mathrm{m}$ x 0,002 $\mathrm{m}$. Sebanyak 12 buah elemen disusun ke dalam pipa berukuran panjang (L) 0,84 $\mathrm{m}$ dan diameter 0,036 m. Pada penelitian ini simulasi hanya dilakukan pada rangkaian modul pengaduk statik, yaitu sejak reaktan masuk melalui inlet minyak dan inlet metanol, hingga keluar dari modul (outlet). Diagram skematik dan ukuran modul pengaduk statik ditunjukkan pada Tabel 1 dan Gambar 2.

Tabel 1. Dimensi Modul Berpengaduk Statik

\begin{tabular}{lr}
\hline \multicolumn{1}{c}{ Parameter } & Ukuran \\
\hline Panjang modul $(\mathrm{mm})$ & 1510 \\
Lebar modul $(\mathrm{mm})$ & 305 \\
Tinggimodul $(\mathrm{mm})$ & 360 \\
Diameter pipa modul (mm) & 36 \\
Panjang elemen $(\mathrm{mm})$ & 70 \\
Lebar elemen $(\mathrm{mm})$ & 36 \\
Tebal elemen $(\mathrm{mm})$ & 2 \\
Sudut puntiran $\left({ }^{\circ}\right)$ & 180 \\
\hline
\end{tabular}

Tahapan pertama dari penelitian ini adalah pembuatan model geometri 3 dimensi dari modul pengaduk statik menggunakan perangkat lunak SolidWorks 2011 berdasarkan ukuran dan bentuk reaktor yang sesungguhnya, seperti ditunjukkan pada Gambar 3.a. Langkah selanjutnya adalah pembuatan grid dengan menggunakan perangkat lunak Meshing (ANSYS Academic Meshing, Release 18.1). Bentuk grid yang digunakan adalah tetrahedral (Gambar 3.b) untuk menyesuaikan dengan model geometri elemen pengaduk statik yang cukup kompleks. Bentuk tetrahedral ini juga sudah digunakan oleh beberapa peneliti untuk model geometrik pengaduk statik seperti Kumar et al. (2008) dan Meng et al. (2013).

Hasil pembuatan grid dinilai kualitasnya dengan menggunakan uji independensi grid. Tahapan uji dilakukan dengan membandingkan nilai skewness, jumlah node, jumlah elemen, dan hasil iterasi. Nilai skewness merupakan salah satu ukuran kualitas grid yang menjelaskan seberapa ideal grid yang dihasilkan. Berdasarkan Fluent Guide, kualitas grid yang baik diperoleh jika nilai skewness maksimum semakin kecil.

Metode penyelesaian

Simulasi aliran minyak dan metanol menggunakan metoda volume hingga dengan asumsi kondisi tunak dan tak-termampatkan (incompressible). Secara umum metode CFD yang digunakan oleh perangkat lunak Fluent (ANSYS Academic Fluent, Release 18.1) melibatkan persamaan kekekalan massa, momentum, dan energi untuk aliran fluida yang dapat dituliskan pada Persamaan 1,2 dan 3, secara berurutan.

$\frac{\partial \rho}{\partial t}+\nabla \cdot(\rho \vec{v})=S_{m}$

$\frac{\partial}{\partial t}(\rho \vec{v})+\nabla \cdot(\rho \vec{v} \vec{v})=-\nabla p+\rho \vec{g}+\vec{F}$

$\frac{\partial}{\partial t}(\rho E)+\nabla \cdot(\vec{v}(\rho E+p))=-\nabla \cdot\left(\sum_{j} h_{j} \vec{J}_{j}\right)+S_{h}$

dimana :

$\rho \quad=\operatorname{densitas}\left(\mathrm{kg} / \mathrm{m}^{3}\right)$

$t \quad=$ waktu (detik)

$v \quad=\operatorname{kecepatan}(\mathrm{m} /$ detik $)$

$S_{m} \quad=$ laju aliran massa volumetrik dari sumber $\left(\mathrm{kg} / \mathrm{m}^{3} \mathrm{~s}\right)$

$\bar{\tau} \quad=$ tensor stres

$g \quad=$ gravitasi $\left(\mathrm{m} / \mathrm{s}^{2}\right)$

$F \quad=$ gaya $(\mathrm{N})$

$h \quad=$ entalpi $(\mathrm{J} / \mathrm{kgmol})$

$S_{h} \quad=$ laju aliran panas volumetrik dari sumber $\left(\mathrm{W} / \mathrm{m}^{3}\right)$

Simulasi aliran minyak dan metanol menggunakan model transfort spesies-finite rate untuk pencampuran dengan melibatkan reaksi kimia. Pada model ini keberlangsungan reaksi kimia yang terjadi ditunjukkan dengan perubahan nilai fraksi massa dari spesies $\left(Y_{i}\right)$, reaktan dan produk, yang diprediksi dengan menggunakan Persamaan 4.

$\frac{\partial}{\partial t}\left(\rho Y_{i}\right)+\nabla \cdot\left(\rho \vec{v} Y_{i}\right)=-\nabla \cdot \vec{J}_{i}+R_{i}+S_{i}$

dengan $R_{i}$ adalah laju produksi dari species $i$ akibat reaksi kimia, $S_{i}$ adalah laju pembentukan akibat sumber-sumber lain, dan $J_{i}$ adalah difusi massa. Perubahan konsentrasi reaktan akan meningkatkan difusi massa yang dihitung menggunakan Persamaan 5.

$\vec{J}_{i}=-\left(\rho D_{i, m}+\frac{\mu_{t}}{S c_{t}}\right) \nabla Y_{i}-D_{T, i} \frac{\nabla T}{T}$

dengan $S c_{t}$ adalah bilangan Schmidt aliran, $\mu_{t}$ adalah viskositas turbulen, dan $D_{t}$ adalah difusivitas turbulen. 


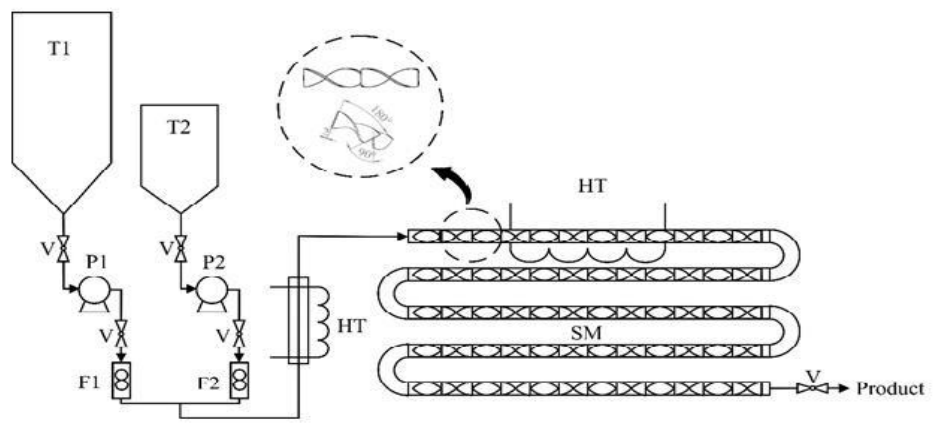

Gambar 2. Diagram skematik reaktor berpengaduk statik tipe kontinu

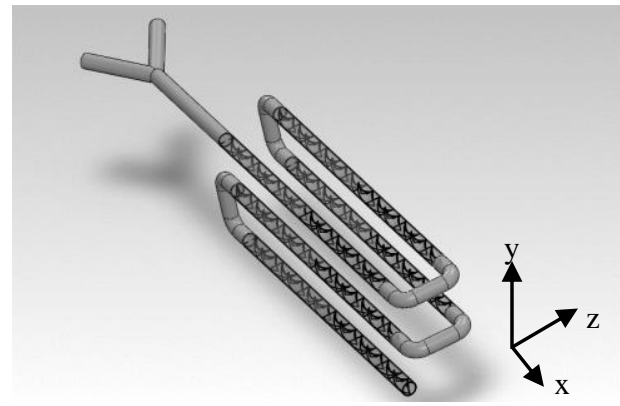

(a)

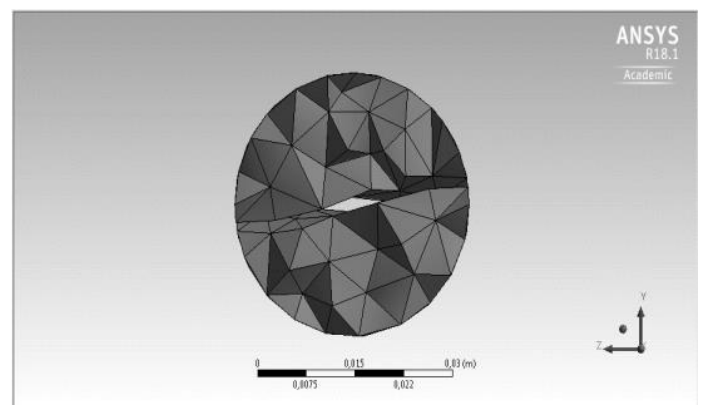

(b)

Gambar 3. (a) Model geometri modul pengaduk statik dan (b) tampilan hasil pembuatan grid

Perangkat lunak ini menyediakan tiga pendekatan untuk menghitung laju reaksi kimia yang dikembangkan untuk reaksi pembakaran, salah satunya adalah model finite rate. Pada model inireaksi kimia atau fraksi produk yang terbentuk bergantung pada laju kinetik reaksi. Perhitungan laju kinetik reaksi pada model finite rate mengikuti persamaan reaksi Arrhenius sehingga penerapan model finite rate untuk reaksi kimia selain reaksi pembakaran dapat dilakukan dengan memasukkan nilai parameter reaksi yang spesifik sesuai dengan reaksi kimia yang akan disimulasikan. Parameter reaksi yang perlu ditentukan pada model finite rate adalah nilai third body efficiency $(\gamma)$, koefisien stoikiometri, energi aktivasi (Ea) dan faktor preekponensial (A). Model finite rate untuk reaksi transesterifikasi sudah dilakukan oleh Adeyemi et al. (2013) menggunakan reaktor berpengaduk mekanik. Laju reaksipada model finite rate mengikuti Persamaan 6.

$R_{i}=M_{w, i} \sum_{r=1}^{N_{R}} R_{i, r}$

dengan $M_{w, i}$ merupakan berat molekul spesies dan $R_{i, r}$ adalah laju molar pembentukan spesies (produk) $i$ pada reaksi transesterifikasi. Jika reaksi terjadi hanya satu arah maka laju molar pembentukan spesies produk akan mengikuti Persamaan 7.

$R_{i, r}=\Gamma\left[-v_{i, r}^{\prime}\left(k_{f, r} \prod_{j=1}^{N}\left[C_{j, r}\right]^{n^{\prime}{ }_{j, r}}\right)\right]$
Laju pembentukan spesies produk dipengaruhi oleh koefisien stoikiometri species reaktan $i$ pada reaksi transesterifikasi $v_{i, r}^{\prime}$, koefisien laju reaksi $k_{f, r}$,konsentrasi molar reaktan $C_{j, \mathrm{r}}$, laju eksponen reaktan $\eta_{\mathrm{j}, \mathrm{r}}$ dan adanya pengaruh total efisiensi third bodies dalam reaksi $\Gamma$. Koefisien laju reaksi didefinisikan pada Persamaan 8

$k_{f, r}=A T^{\beta} e^{-\frac{E a}{R T}}$

dengan $\mathrm{T}$ adalah suhu reaksi dan $\beta$ adalah konstanta yang pada penelitian ini diasumsikan bernilai nol untuk menyesuaikan dengan persamaan Arrhenius yang umumnya diterapkan pada reaksi transesterifikasi. Selanjutnya dengan memasukkan Persamaan 7 dan 8 ke dalam Persamaan 6 diperoleh laju molar pembentukan produk pada Persamaan 9

$$
R_{i}=M_{w, i}\left\{\Gamma\left[-v_{i, r}^{\prime}\left(A e^{-\frac{E a}{R T}} \prod_{j=1}^{N}\left[C_{j, r}\right]^{n_{j, r}^{\prime}}\right)\right]\right\}
$$

\section{Kondisi Batas}

Pada tahap ini diperlukan properti dari reaktan dan produk yang dirangkum pada Tabel 2 . Selain properti bahan, kondisi awal reaksi seperti laju aliran massa reaktan, intensitas turbulensi pada inlet, dan suhu awal reaktan, juga ditentukan pada tahap ini. Nilai parameter yang digunakan kondisi awal reaksi akan dijelaskan pada bagian hasil dan pembahasan. 
Tabel 2. Properti bahan pada reaksi transesterifikasi

\begin{tabular}{|c|c|c|c|c|c|}
\hline Bahan & $\begin{array}{c}\text { Berat molekul (kg } \\
\left.\text { kmol }^{-1}\right)\end{array}$ & $\begin{array}{c}\text { Densitas } \\
\left(\mathrm{kg} \mathrm{m}^{-3}\right)\end{array}$ & $\begin{array}{c}\text { Kapasitas } \\
\text { panas } \\
\left(\mathrm{J} \mathrm{kg}^{-1} \mathrm{~K}^{-1}\right)\end{array}$ & $\begin{array}{l}\text { Konduktivitas } \\
\qquad\left(\mathbf{W} \mathbf{m}^{-1} \mathbf{K}^{-1}\right)\end{array}$ & $\begin{array}{r}\text { Viskositas } \\
\left(\mathrm{kg} \mathrm{m}^{-1} \mathrm{~s}^{-1}\right)\end{array}$ \\
\hline Minyak & 850.76 & $870^{\mathrm{a}}$ & $1861^{b}$ & $0.17^{b}$ & $0.03 a$ \\
\hline Metanol & 32.03 & 785 & 2534 & 0.20 & $5.5 \times 10^{-4}$ \\
\hline FAME & 284.94 & $852^{c}$ & $2020 d$ & $0.14^{\mathrm{e}}$ & $4.5 \times 10^{-3 a}$ \\
\hline Gliserol & 92.06 & 1259.9 & 2437 & 0.29 & 0.799 \\
\hline
\end{tabular}

Tabel 3. Skenario laju aliran reaktan untuk simulasi

\begin{tabular}{ccccccc}
\hline & $\mathbf{1}$ & $\mathbf{2}$ & $\mathbf{3}$ & $\mathbf{4}$ & $\mathbf{5}$ & Unit \\
\hline Minyak & 5 & 8 & 13 & 15 & 20 & L/menit \\
Metanol & 0,6 & 0,96 & 1,6 & 1,8 & 2,4 & L/menit \\
\hline
\end{tabular}

Hasil perhitungan menggunakan model pada metode penyelesaian dibandingkan data eksperimen sebagai langkah validasi. Selanjutnya digunakan pada simulasi dengan menggunakan 5 skenario laju aliran massa untuk melihat pengaruhnya terhadap profil aliran dan ketercampuran reaktan, minyak dan metanol, di sepanjang modul. Skenario yang digunakan pada penelitian ini ditunjukkan pada Tabel 3. Laju aliran massa kedua bahan diperbesar bertujuan agar semakin besar pergolakan aliran fluida di dalam pipa reaktor sehingga pencampuran dapat dicapai lebih cepat.

\section{HASIL DAN PEMBAHASAN}

\section{Uji Independensi Griddan Validasi Model}

Simulasi dengan menggunakan metode volume hingga, seperti yang dipakai pada CFD, sangat bergantung pada ukuran dan jenis grid yang dibuat karena akan mempengaruhi ketepatan hasil simulasi. Untuk menentukan kualitas grid diperlukan pengujian dengan membandingkan parameter simulasi yang dihasilkan. Dalam penelitian ini digunakan jenis grid tetrahedral dengan interval ukuran 5-7 mm. dan dihitung berdasarkan Persamaan 10. Berdasarkan nilai skewness yang diperoleh pada Tabel 4, ukuran grid $6 \mathrm{~mm}$ memiliki nilai skewness paling kecil. Selain nilai skewness, uji independesi grid juga dilakukan dengan membandingkan fraksi FAME yang dihasilkan. Berdasarkan nilai skewness dan fraksi FAME pada Gambar 4, ukuran $6 \mathrm{~mm}$ memiliki parameter grid yang cukup baik untuk digunakan dalam validasi model.

Skewness $=\frac{\text { Ukuran grid optimal }- \text { ukuran grid }}{\text { ukuran grid optimal }}$

Validasi model dilakukan dengan membandingkan data simulasi dengan data eksperimen. Nilai parameter reaksi yang digunakan pada simulasi ditunjukkan pada Tabel 5. Nilai parameter reaksi ini merupakan nilai parameter pada kondisi awal reaksi. Data eksperimen produksi biodiesel menggunakan reaktan minyak sawit dan metanol dengan rasio molar 1:6, katalis $\mathrm{KOH} 0,5 \%$ dari berat minyak, suhu minyak dan metanol masing-masing $65^{\circ} \mathrm{C}$ dan $28^{\circ} \mathrm{C}$. Penggunaan rasio molar yang lebih besar pada eksperimen adalah untuk memastikan tidak terjadi reaksi balik, sementara pada simulasi hal ini dapat dilakukan dengan pemilihan opsi reaksi tak-balik yang tersedia pada perangkat lunak.

Tabel 4. Uji independensi grid

\begin{tabular}{llll}
\hline Parameter & $\mathbf{1}$ & $\mathbf{2}$ & $\mathbf{3}$ \\
\hline Ukuran (m) & 0,005 & 0,006 & 0,007 \\
$\begin{array}{l}\text { Skewness } \\
\text { maksimum }\end{array}$ & 0,9887 & 0,7329 & 0,7837 \\
$\begin{array}{l}\text { Skewness rata-rata } \\
\text { Jumlah node (buah) }\end{array}$ & 0,2510 & 0,2510 & 0,2560 \\
$\begin{array}{l}\text { Jumlah elemen } \\
\text { (buah) }\end{array}$ & 254628 & 52733 & 37606 \\
\hline
\end{tabular}

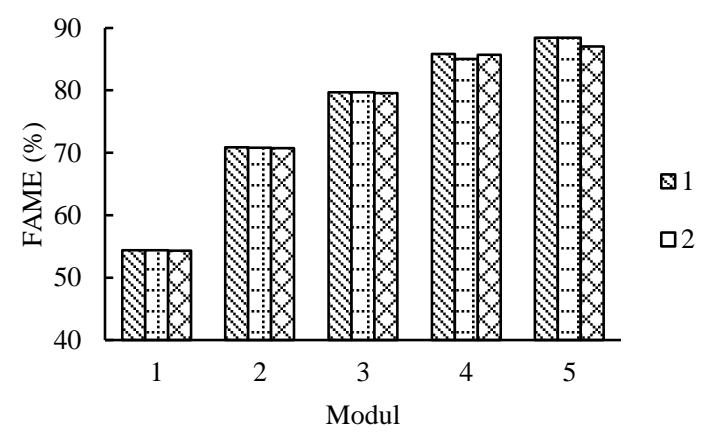

Gambar 4.Perbandingan kadar FAME menggunakan ukuran grid 1, 2, dan 3

Tabel 5. Parameter Simulasi

\begin{tabular}{lr}
\hline Parameter simulasi & Nilai \\
\hline Laju aliran massa (L/menit) & 10 \\
Minyak & 1,2 \\
Metanol & 15,997 \\
A & $1,4 \mathrm{E}+07$ \\
Ea (J/kmol) & 0,4 \\
$\gamma$
\end{tabular}


Sampel produk hasil eksperimen berupa biodiesel mentah di kelima modul diambil secara bersamaan. Lima sampel biodiesel mentah yang telah diperoleh kemudian diendapkan dan dicuci untuk menghilangkan produk sampingan dan pengotor seperti gliserol dan sisa metanol yang tidak bereaksi serta katalis. Biodiesel hasil pemurnian selanjutnya diuji pada laboratorium untuk mendapatkan kadar FAME. Kajian eksperimental dan prosedur pengambilan data eksperimen diuraikan dengan lebih rinci pada Sari et al. (2016). Data kadar FAME hasil eksperimental selanjutnya dibandingkan dengan data FAME hasil simulasi yang ditampilkan pada Gambar 5. Hasil perbandingan tersebut menunjukkan bahwa model simulasi yang digunakan dapat menggambarkan keadaan nyata dengan cukup baik.

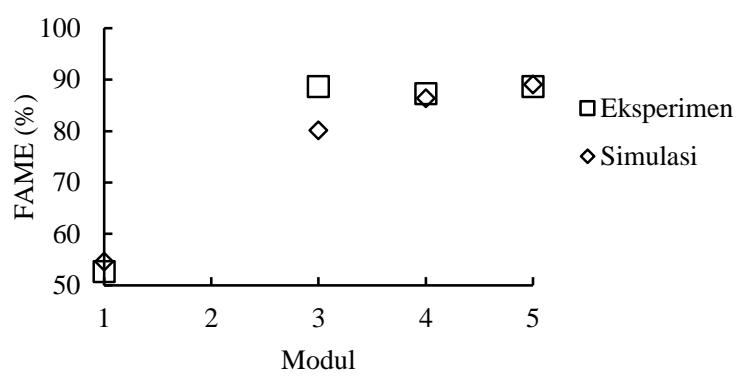

Gambar 5. Validasi model

\section{Profil Aliran di Dalam Reaktor \\ Kecepatan}

Kecepatan merupakan salah satu parameter yang berpengaruh terhadap profil suatu aliran sehingga dapat digunakan untuk mempelajari karakteristik pencampuran fluida (Hobbs et al., 1998). Hasil simulasi lima skenario laju aliran yang dilakukan pada penelitian ini ditunjukkan dalam bentuk kontur kecepatan pada Gambar 6. Data kontur diambil dari penampang melintang reaktor berupa bidang sampling setelah aliran fluida (campuran minyak dan reaktan) melewati elemen ketiga dari 12 elemen pada modul 1, 3, dan 5 . Berdasarkan gradasi warna pada kontur yang diperoleh dari simulasi terlihat bahwa peningkatan laju aliran massa berbanding lurus dengan peningkatan kecepatan aliran fluida. Selanjutnya, nilai kecepatan aliran fluida, yang diperoleh dari garis sampling di sepanjang diameter pipa reaktor yang dibuat pada bidang sampling yang ditampilkan pada Gambar 7.

Pada skenario yang sama besaran kecepatan aliran fluida tidak menunjukkan perubahan yang signifikan di sepanjang modul. Hal ini sesuai dengan penelitian yang dilakukan oleh Kumar et al. (2008) yang menyebutkan bahwa laju aliran pada inlet tidak berbeda dengan laju aliran fluida di bagian outlet. Transisi antar elemen memberi pengaruh terhadap kecepatan aliran fluida di dalam pipa berpengaduk hingga 25\% (Hobbs et al., 1998). Kecepatan aliran hanya mengalami perubahan pada daerah yang berdekatan dengan elemen pengaduk statik. Laju aliran fluida yang bersentuhan dengan dinding pipa dan badan elemen pengaduk mempunyai nilai yang lebih kecil. Hal ini terjadi akibat adanya gesekan antara fluida dengan dinding, sedangkan aliran akan berkembang lebih baik pada daerah bebas. Elemen pengaduk yang berbentuk helikal mengakibatkan fluida mengalami proses pembagian, peregangan, pembalikan, dan pencampuran selama mengalir di sepanjang elemen pengaduk.

Pada pipa tanpa adanya pengaduk, Gambar 8 , menunjukan bahwa kecepatan paling besar berada pada tengah pipa dan daerah yang berdekatan dengan dinding pipa mempunyai nilai lebih kecil. Hal ini terjadi akibat adanya gesekan antara fluida dan dinding yang lebih besar dibandingkan pada daerah jauh dari dinding pipa. Aliran fluida dapat berkembang disepanjang pipa, namun kedua bahan pada sisi.

Skenario 1
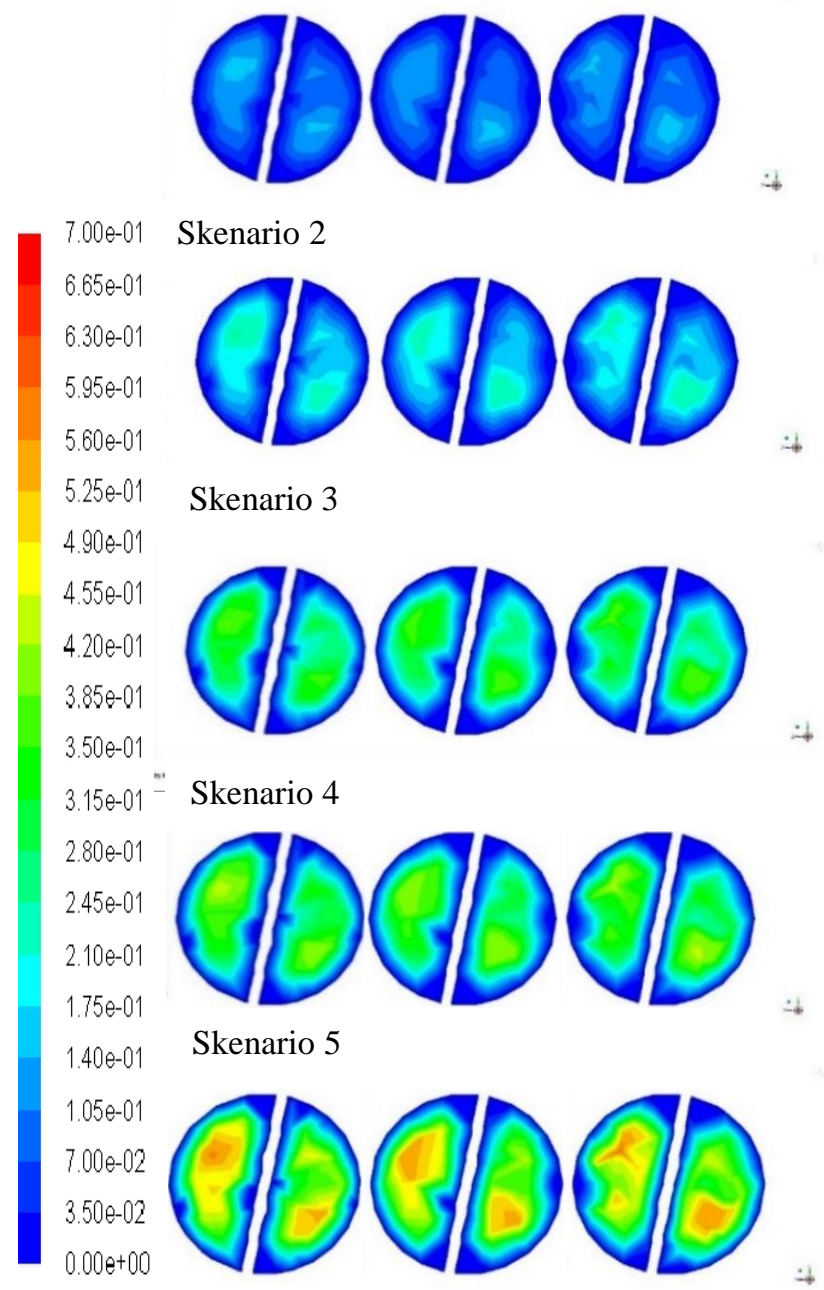

$\operatorname{Kecepatan}(\mathrm{m} / \mathrm{s})$

Gambar 6. Kontur kecepatan setelah aliran fluida melewati elemen ketiga di modul 1, 3, 5 untuk masing-masing skenario 

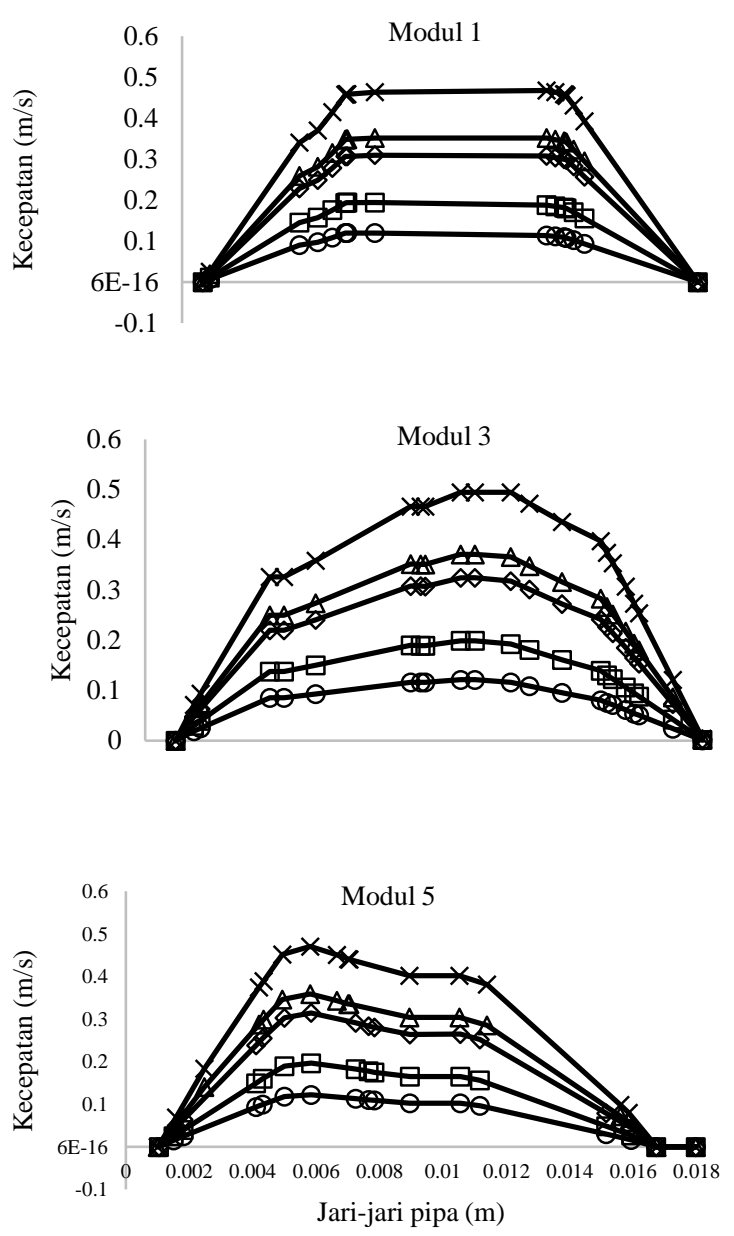

- Skenario $1 \square$ Skenario 2 Skenario $3 \Delta$ Skenario $4 \times$ Skenario 5

Gambar 7. Grafik kecepatan di sepanjang jari-jari pipa reaktor

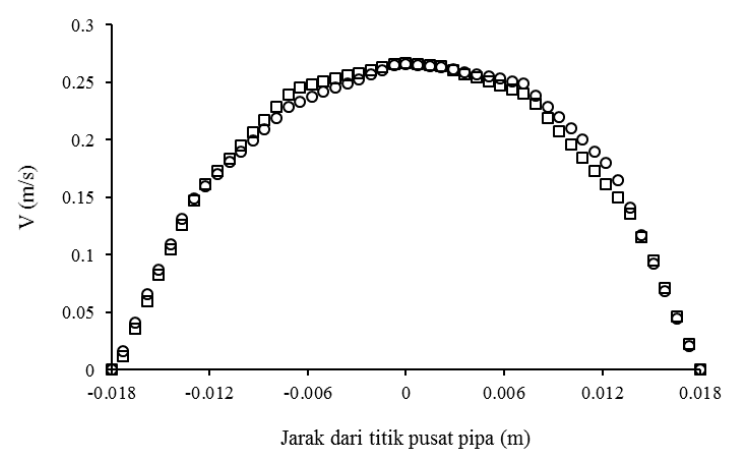

Gambar 8. Kecepatan aliran pada pipa tanpa pengaduk

Pergerakan aliran fluida di sepanjang elemen dapat jelaskan dengan melacak jejak partikel pada sumbu $\mathrm{x}, \mathrm{y}$, dan $\mathrm{z}$ seperti ditunjukkan pada Gambar 9. Jejak partikel diambil pada saat aliran fluida melewati elemen pertama pada skenario 5 dengan kecepatan aliran pada sumbu x (arah aksial) pada kisaran 0,4-0,5 m/s. Nilai kecepatan pada sumbu $\mathrm{x}$ dipengaruhi oleh kecepatan aliran minyak pada inlet. Aliran fluida juga mengalami pergerakan ke arah kiri-kanan yang dinyatakan dengan nilai kecepatan pada sumbu $\mathrm{z}$ dan pergerakan ke arah atas-bawah pada sumbu y. Profil pergerakan pada sumbu y dan $\mathrm{z}$ menunjukkan terjadinya perubahan arah gerakan partikel selama mengalir di sepanjang reaktor. Setelah aliran fluida mengalami pembalikan sebesar $90^{\circ}$, aliran fluida memasuki elemen selanjutnya dan mengalami pembagian aliran akibat sisi elemen. Menurut Hobbs et al. 1998, pola aliran fluida di dalam pipa berpengaduk statik akan berulang secara periodikal di setiap elemen pengaduk akibat bentuk geometri dari elemen pengaduk yang sama. Peningkatan laju aliran pada inlet yang diikuti dengan peningkatan kecepatan dan pola aliran yang terus dipertahankan di sepanjang pengaduk, maka peluang pencampuran reaktan akan semakin besar.

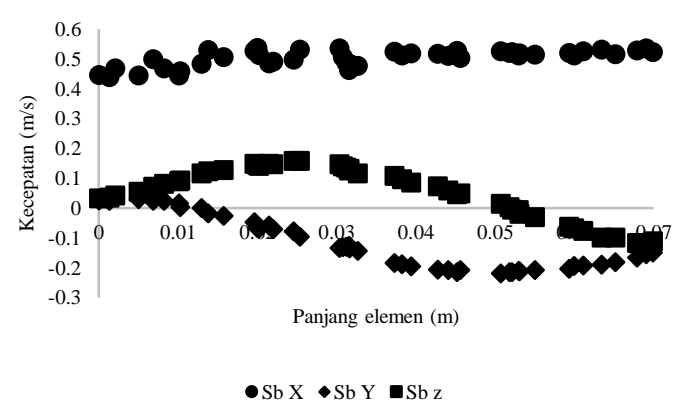

Gambar 9. Profil kecepatan sumbu x, y, z partikel ketika melewat elemen pertama di modul 1 (Skenario 5)

Pergerakkan aliran fluida di setiap elemen dapat diketahui dengan mengikuti jejak partikel pada pathline, seperti ditunjukkan pada Gambar 10. Jejak partikel diambil pada saat aliran fluida melewati elemen 1 hingga elemen ke 3 di modul 1. Aliran fluida mengalami pergerakan ke arah atas-bawah yang dinyatakan dengan nilai kecepatan pada sumbu y dan pergerakan ke arah kiri-kanan pada sumbu z. Profil pergerakan pada sumbu y dan z menunjukkan terjadinya perubahan arah gerakan partikel selama mengalir di sepanjang reaktor. Setelah aliran fluida mengalami pembalikan sebesar $90^{\circ}$, aliran fluida memasuki elemen selanjutnya dan mengalami pembagian aliran akibat sisi elemen.
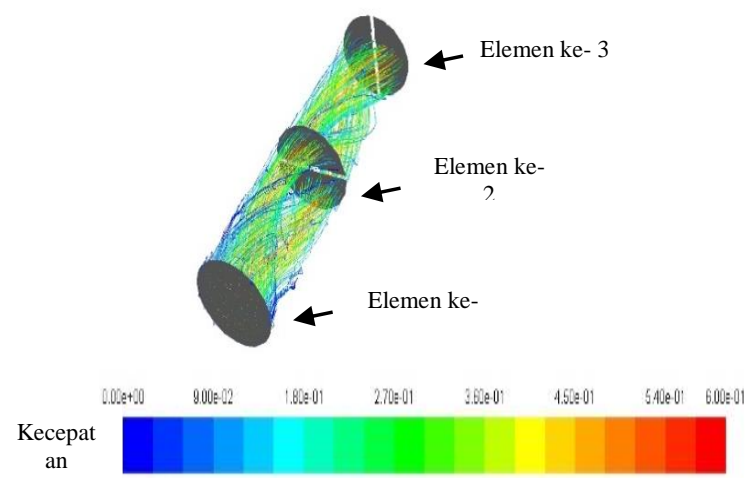

Gambar 10. Pergerakan aliran fluida antar elemen pengaduk pada modul 1 


\section{Vortisitas}

Pergerakan molekul reaktan ke berbagai arah di dalam pipa reaktor menunjukkan terjadinya pola aliran yang berbentuk seperti putaran. Keberadaan elemen pengaduk statik di dalam pipa sebetulnya adalah sebuah hambatan yang mempengaruhi gerakan molekul (Meng et al., 2015) yang berfungsi sebagai pemacu pergolakan aliran fluida sehingga dapat meningkatkan efektivitas pencampuran. Hal ini dapat dikaitkan dengan vortisitas yang merupakan ukuran untuk menyatakan pergerakan berputar dari suatu molekul di dalam sebuah aliran. Pada jenis pengaduk statik, vortisitas yang terjadi adalah tipe longitundinal, yaitu perputaran aliran berlangsung mengikuti aliran fluida di dalam pipa. Adanya vortisitas aliran akan mengakibatkan lapisan aliran laminar di daerah dekat dinding pipa berkurang akibat terbentuknya turbulensi yang mampu meningkatkan transfer secara konvektif (Kaci et al., 2010). Nilai vortisitas

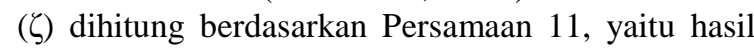
perkalian vektor nilai derivasi kecepatan terhadap masing-masing sumbu $\mathrm{x}, \mathrm{y}$, dan $\mathrm{z}$.

$$
\zeta=\nabla \times \vec{V}
$$

Berdasarkan hasil derivasi besaran kecepatan terhadap masing-masing sumbu $\mathrm{x}$, $\mathrm{y}$ dan $\mathrm{z}$, maka diperoleh nilai gradien kecepatan di modul 1 yang ditunjukkan pada Gambar 11. Kelengkungan profil kecepatan yang terbentuk pada masing-masing sumbu $\mathrm{x}, \mathrm{y}$, dan $\mathrm{z}$ menunjukkan gradien kecepatan aliran yang terjadi di sepanjang diameter pipa. Semakin besar kelengkungan dari profil kecepatan, maka semakin besar gradien kecepatan aliran yang nantinya mempengaruhi keseragaman vortisitas. Sebagaimana penjelasan di atas, vortisitas merupakanperkalian vektordari gradien kecepatan di masing-masing sumbu $\mathrm{x}, \mathrm{y}$, dan $\mathrm{z}$.

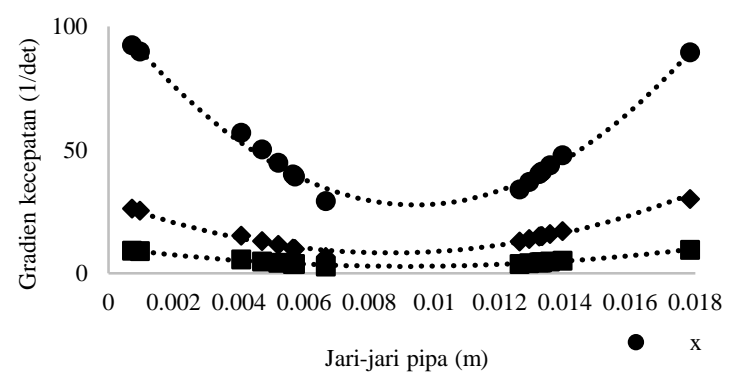

Gambar 11. Profil gradien kecepatan masing-masing sumbu $\mathrm{x}, \mathrm{y}, \mathrm{z}$ pada elemen ketiga di modul 1 (Skenario 3)

Pada penelitian ini, simulasi dengan lima skenario laju aliran massa menghasilkan kontur vortisitas yang bervariasi di sepanjang diameter pipa (Gambar 12). Teraan profil tersebut ke dalam grafik vortisitas terhadap jari-jari pipa ditunjukkan pada Gambar 13. Peningkatan laju aliran reaktan menyebabkan profil kecepatan yang semakin melengkung sehingga menyebabkan vortisitas semakin tidak seragam di sepanjang jari-jari pipa, seperti ditunjukkan oleh perbedaan skenario pada masing-masing modul. Perbandingan antar modul pada skenario yang sama menunjukkan adanya peningkatan keseragaman vortisitas pada modul terjauh dari inlet.

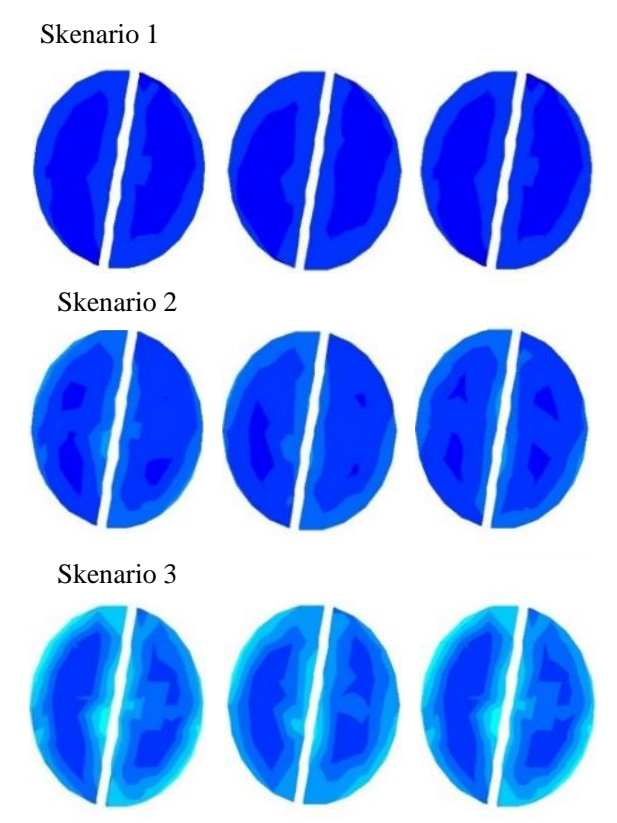

Skenario 4

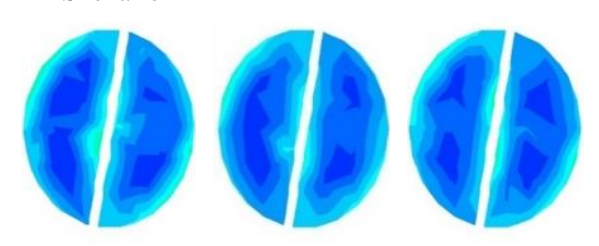

Vortisi

tas

Skenario 5

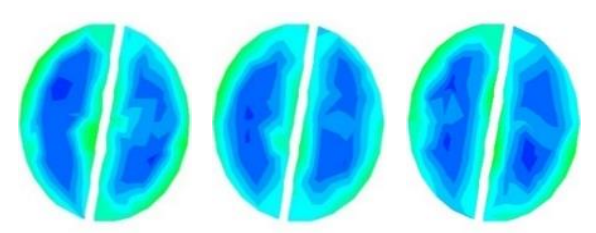

Gambar12. Kontur vortisitas di modul 1, 3, dan 5 untuk setiap skenario

Kondisi aliran yang memiliki vortisitas seragam menunjukkan bahwa aliran tidak hanya terjadi ke arah arus utama (arah aksial) tetapi juga terjadi gerakan acak ke arah sumbu y dan z, serta terjadinya gerakan rotasi sebagai akibat dari keberadaan elemen pengaduk di dalam pipa. Kondisi vortisitas di sepanjang pengaduk diperkirakan berpengaruh terhadap ketercampuran molekulmolekul reaktan, yang pada akhirnya akan meningkatkan peluang terjadinya reaksi antar molekul reaktan tersebut. Dengan demikian, vortisitas dapat digunakan sebagai parameter kuantifikasi ketercampuran fluida di dalam reaktor 
berpengaduk statik, meskipun pengaruh vortisitas terhadap laju reaksi yang dihasilkan perlu dikaji lebih lanjut.
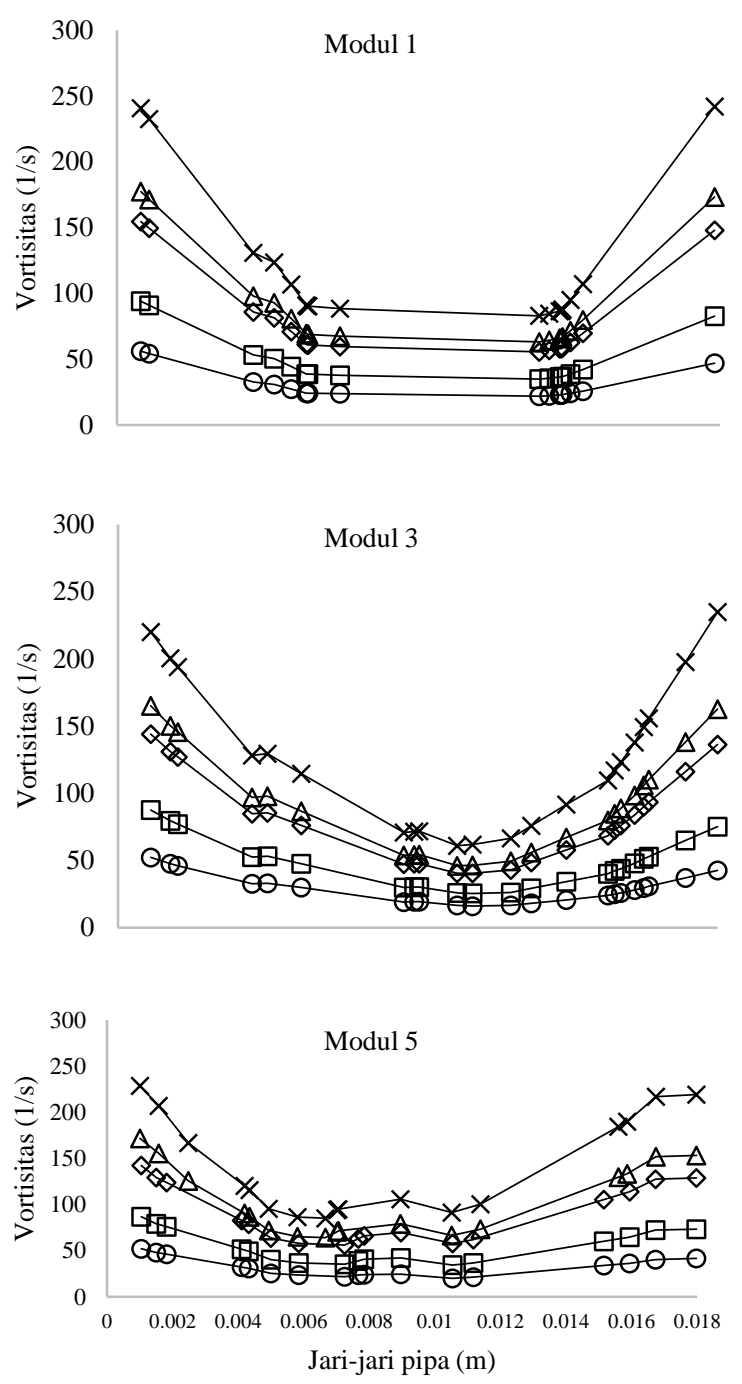

- Skenario $1 \square$ Skenario 2 - Skenario $3 \Delta$ Skenario $4 \times$ Skenario 5

Gambar 13.Perbandingan vortisitas antar modul disepanjang jari-jari pipa

\section{KESIMPULAN DAN SARAN}

\section{Kesimpulan}

Keberadaan elemen pengaduk di dalam pipa reaktor berpengaduk statis (mempengaruhi profil aliran fluida di dalam reaktor). Aliran fluida tidak hanya terjadi ke arah arus utama (arah aksial) tetapi juga terjadi gerakan acak ke arah sumbu y dan z, serta gerakan rotasi. Terjadinya gerakan acak tersebut mempengaruhi ketercampuran fluida, dan dapat dikuantifikasi dengan nilai vortisitas.

\section{Saran}

Pengaruh pengaduk statik terhadap laju reaksi perlu dikaji lebih lanjut, terutama terhadap parameter pencampuran (vortisitas)yang dihasilkan disepanjang pipa reaktor berpengaduk statik untuk memperoleh konversi reaksi yang maksimal.

\section{UCAPAN TERIMA KASIH}

Ucapan terima kasih disampaikan kepada Direktorat Jenderal Penguatan Riset dan Pengembangan Kementrian Riset, Teknologi, dan Perguruan Tinggi Republik Indonesia yang sudah mendukung penelitian ini dalam Penelitian Magister Doktor Sarjana Unggulan (PMDSU) Tahun 2016, Nomor : 2200/IT3.11/LT/2016 tanggal 8 September 2016.

\section{DAFTAR PUSTAKA}

Adeyemi NA, Mohiuddin AKM, Nor MIM. 2013. CFD modeling of waste cooking oil transesterification in stirred tank reactor. World Applied Science Journal 21: 151158.

An H, Yang WM, Maghbouli A, Chou SK, Chua KJ. 2013. Detailed physical properties prediction of pure methyl esters for biodiesel combustion modeling. Applied Energy. 102: 647-656.

Anand K, Sharma RP, dan Mehta PS. 2011. A comprehensive approach for estimating thermo-physical properties of biodiesel fuels. Applied Thermal Eng. 31: 235-242. Budiman A, Kusumaningtyas RD, Pradana YS, Lestari NA. 2017. Biodiesel: Bahan Baku, Proses, dan Teknologi. Yogyakarta: Gadjah Mada Universitas Press.

Chempro G India. 2017. Palm oil properties [internet]. [diacu 2017 Januari 30]. Tersedia dari:

http://www.chempro.in/palmoilproperties.ht $\mathrm{ml}$.

Darnoko D dan Cheryan M. 2000. Kinetics of palm oil transesterification in a batch reactor. Journal American Oil Chemists Society. 77(12): 1263-1267.

FLUENT 18.1 User' Guide. 2017. Fluent Inc

Garpen JV. 2005. Biodiesel processing and production. Fuel Processing Techology. 86: 1097-1107.

Hobbs DM, Swanson PD, dan Muzzio FJ. 1998. Numerical characterization of low reynolds number flow in the kenics staticmixer. Chemical Engineering Science. 53(8): 1565-1584.

Kaci H M, Habchi C, Lemenand T, Valle DD, Peerhossaini H. 2010. Flow structure and heat transfer induced by embedded vorticity. International Journal Heat and Mass Transfer. 53: 3575-3584. 
Knothe G, Gerpen JV, dan Krahl J. 2005. The Biodiesel Handbook. Champaign, Illinois (US): AOCS Press.

Kumar V, Shikre V, dan Nigam KDP. 2008. Performance of kenic static mixer over a wide range of reynold number. Chemical Engineering Journal. 139: 284-295.

Ma F dan Hanna MA. 1999. Biodiesel production: a review ${ }^{1}$. Bioresource Technology. 70: 1-15.

Meng H, Song M, Yu Y, Wang F, Wu J. 2015. Chaotic mixing characteristics in static mixers with different axial twisted-tape inserts. The Canadian Journal Chem Eng. 93: 1849-1859.

Panggabean S. 2011. Analisis kinetika reaksi transesterifikasi pada produksibiodiesel secara katalitik dengan static mixing reactor [Tesis]. Bogor (ID): Institut Pertanian Bogor.

Sari SP, Tambunan AH, dan Nugroho LPE. 2016. Penggunaan pengaduk statik untuk mengurangi kebutuhan katalis dalam produksi biodiesel. Jurnal Teknologi Industri Pertanian. 26(3): 236-245.

Sigma A. 2017. Methyl palmitate. [internet]. [diacu 2017 Januari 30]. Tersedia dari: https://www.sigmaaldrich.com/catalog/prod uct/sigma/p5177?lang=en\&region=ID.

Sivasamy A,Cheah KY, Fornasiero P, Kemausuor F,Zinoviev S, Miertus S. 2009. Catalytic applications in the production of biodiesel fromvegetable oils. Chemsuschem. 2: 278300 .

Soolany C, Tambunan AH, dan Sudradjat R. 2015. Kajian penggunaan static mixing reactor pada proses produksi biodieselsecara katalitik dengan sistem kontinu. Jurnal Penelitian Hasil Hutan. 33(3): 261-272.

Sungwornpatansakul P, Hiroi J, Nigahara Y, Jayasinghe TK, Yoshikawa K. 2013. Enhancement of biodiesel production reaction employing the static mixing. Fuel Processing Tech. 116: 1-8.

Wen Z dan Petera J. 2015. CFD numerical simulation of biodiesel synthesis in a spinning disc reactor. Chemical Process Engineering. 36(1): 21-37. 